\title{
RITUXIMAB MAINTENANCE STRATEGY IN ADVANCED FOLLICULAR LYMPHOMA: FACTS AND CONTROVERSIES
}

\author{
Vibor Milunović, ${ }^{1,2}$, Martina Bogeljić Patekar ${ }^{1}$, Karla Mišura Jakubac ${ }^{1}$, Inga Mandac Rogulj ${ }^{1}$, \\ Delfa Radić-Krišto ${ }^{1}$, Ana Planinc-Peraica ${ }^{1,3}$ and Slobodanka Ostojić Kolonić ${ }^{1,3}$ \\ ${ }^{1}$ Division of Hematology, Merkur University Hospital, Zagreb, Croatia; \\ ${ }^{2}$ Lombardi Comprehensive Cancer Centre, Georgetown University, Washington D.C., USA; \\ ${ }^{3}$ School of Medicine, University of Zagreb, Zagreb, Croatia
}

\begin{abstract}
SUMMARY - Rituximab is a chimeric monoclonal CD20 antibody used in the treatment of CD20 positive non-Hodgkin lymphomas and has revolutionized treatment approach to these hematologic malignancies in the last decade. The main aim of this review is to present data on the use of rituximab in the treatment of follicular lymphoma (FL). We will focus on rituximab maintenance strategies in the first and second line treatment. This approach has improved the outcome in FL patients with better progression-free survival in all patients and better overall survival in relapsed setting. Regardless of good results, this strategy has generated controversies in medical community in the range from the lack of overall survival benefit in first line setting, adverse effects of possible overtreatment and toxicities to its unknown role in the era of novel agents. The existing data suggest that rituximab maintenance should be a rational therapeutic option for all patients with FL responding to first line therapy and transplant-ineligible patients responding to reinduction.
\end{abstract}

Key words: Rituximab; Lymphoma, non-Hodgkin - therapy; Lymphoma, follicular; Maintenance chemotherapy; Treatment outcome

\section{Introduction}

Follicular lymphoma (FL) is one of the most common subtypes of non-Hodgkin lymphoma (NHL). A recent survey in the United States that included 596,476 patients with newly diagnosed NHL over a period of 14 years demonstrated that FL was the second most common subtype of NHL, accounting for $17.1 \%$ of cases $^{1,2}$. In Croatia, the incidence of NHL is 5.57 per 100,000 of men or women, as reported by Novak et al. for the 2005-2009 period ${ }^{3}$. FL accounts for $20.2 \%$ of NHL cases in Croatia as demonstrated re-

Correspondence to: Vibor Milunović, MD, Lombardi Comprehensive Cancer Centre, Georgetown University, 3970 Reservoir Road NW E501, 20007 Washington D.C., United States of America (current address)

E-mail: v_milunov@net.hr

Received February 10, 2015, accepted April 25, 2016 cently by the international NHL classification project ${ }^{4}$. The histology of FL is characterized by germinal centers of B lymphocytes, predominantly centrocytes and centroblasts with follicular growth pattern ${ }^{2,5}$. They harbor universal translocation $\mathrm{t}(14 ; 18)(\mathrm{q} 32 ; \mathrm{q} 21)$ involving the rearrangement of BCL2 and $\mathrm{IgH}$ in most cases. Morphologically, four different grades are recognized, based on the number or centroblasts per high power field with FL grade $4 \mathrm{~b}$ being a distinct entity due to different biological and clinical behavior ${ }^{2,6}$. It is also characterized by expression of BCL2, BCL6, CD20, CD19 and monoclonal immunoglobulin light chain.

The course of the disease is marked by indolent course, frequent relapses, 'incurability', and tendency to transform into more aggressive NHL (diffuse large B cell lymphoma). It is important to note that not all patients are treated initially due to the 'watch and wait' 
Table 1. GELF proposal as a reason to start treatment

\begin{tabular}{|l|}
\hline Reason to start treatment \\
\hline Involvement of 3 nodal sites (diameter $\geq 3 \mathrm{~cm}$ ) \\
Any tumor mass greater than $7 \mathrm{~cm}$ \\
B symptoms \\
Pleural effusion or ascites \\
Cytopenia (leukopenia, thrombocytopenia) \\
Leukemia ( $\geq 5 \times 10^{9}$ of malignant cells) \\
\hline
\end{tabular}

Table 2. Risk stratification according to FLIPI-1 and FLIPI-2 $2^{10,11}$

\begin{tabular}{|l|l|}
\hline Prognostic score \\
\hline FLIPI- ${ }^{*}$ & FLIPI-2** \\
\hline Age $\geq 60$ years & $\begin{array}{l}\text { Beta } 2 \text { microglobulin } \\
\geq U L N\end{array}$ \\
\hline Ann Arbor stage III or IV & Bone marrow involvement \\
\hline Hemoglobin $\leq 120 \mathrm{~g} / \mathrm{L}$ & Age $>60$ years \\
\hline Serum LDH $\geq \mathrm{ULN}$ & Hemoglobin $\leq 120 \mathrm{~g} / \mathrm{L}$ \\
\hline Number of nodal sites $\geq 5$ & $\begin{array}{l}\text { Longest nodal diameter } \\
>6 \mathrm{~cm}\end{array}$ \\
\hline
\end{tabular}

*number of factors: 0-1 low risk group; 2 intermediate risk group; 3 or more high risk group; **number of factors: 0 low risk group; $1-2$ intermediate risk group; 3 or more high risk group; ULN = upper normal limit; $\mathrm{LDH}=$ lactate dehydrogenase

strategy. The most commonly used treatment criteria (GELF) are presented in Table $1^{7}$. Controversies remain regarding treatment rationale in cases of low tumor mass ${ }^{8,9}$. Furthermore, newly diagnosed FL patients should be stratified according to FLIPI-1 or FLIPI-2 criteria (Table 2) in order to predict the outcomes and overall survival $(\mathrm{OS})^{10,11}$.

The main aim of this review is to analyze the existing data on the current treatment of FL with special emphasis on maintenance therapy.

\section{Historical Overview of Advances in Follicular Lymphoma Therapy}

Prognosis in patients diagnosed with FL was poor. In a retrospective single-center analysis from the 1970 s, the 5 -year OS was $54 \%$, deteriorating to $34 \%$ in patients older than $50^{12}$. Disease-free survival after 5 -year follow up was only $18 \%$ of patients. However, these numbers improved as outlined by the recent EU-
ROCARE 5 report $^{13}$. A subanalysis for hematologic malignancies was performed for 1997-2007 including $32,110 \mathrm{FL}$ cases $^{14}$. Considerable improvement was recorded in 5-year OS of FL patients and in comparison to other lymphoid malignancies, rising from $58.9 \%$ in the $1997-1999$ period to $74.3 \%$ in the $2006-2008$ period. There are several reasons for this improvement in outcomes, but for the purpose of this review we will state only two, i.e. the widespread introduction of rituximab, a chimeric antiCD20 antibody, and improvement in autologous stem cell transplantation (ASCT).

In the report of the European Society for Blood and Marrow Transplantation (EBMT) study, which included 693 patients followed-up for at least 15 years, the outcomes of ASCT for FL are presented ${ }^{15}$. The median progression-free survival (PFS) at 5, 10 and 15 years was $41 \%, 28 \%$ and $26 \%$, respectively, with a plateau in the survival curve indicating satisfactory disease control in one-quarter of patients with relapsed or refractory FL. The median OS for ASCT at 5, 10 and 15 years was $64 \%, 52 \%$ and $47 \%$, respectively. In a study of 121 patients undergoing ASCT at second remission or subsequent relapse, followed-up for at least 12 years, PFS was $55 \%$ at 5 year and $48 \%$ at 10 years $^{16}$. These results also show adequate tumor control, which can be obtained by ASCT. The only factor associated with longer OS was ASCT at $2^{\text {nd }}$ complete remission (CR). This treatment approach was also embraced officially by the leading international guidelines and subsequently by the Croatian Society of Hematology and Transfusion in the national lymphoma guidelines ${ }^{17-19}$.

Another important improvement in the treatment of FL patients was the introduction of rituximab. The pivotal study included 166 patients with relapsed FL or other low grade NHL on infusion regimen with $375 \mathrm{mg} / \mathrm{m}^{2}$ once weekly for 4 weeks $^{20}$. The overall response rate (ORR) was 48\% and PFS 13 months. Toxicities were mild and the efficacy was comparable to the cyclophosphamide, doxorubicin, vincristine and prednisone (CHOP) chemotherapy regimen, then considered as the gold standard for indolent lymphomas. This study led to approval of rituximab for relapsed indolent NHL in $1997^{21}$. With its impressive activity and low toxicity profile, the question arose if rituximab could be further combined with conventional chemotherapy to improve outcomes in these patients. Preliminary data on preclinical models sup- 
ported in vivo synergistic effects of rituximab with cytotoxic drugs ${ }^{22}$. However, it took years to translate these findings into clinical reality. The first pivotal randomized trial published in 2005 compared cyclophosphamide, vincristine and prednisone (CVP) with rituximab-CVP (R-CVP) ${ }^{23}$. It included 321 patients with stage III or IV FL. Primary objective was time to treatment failure (TTTF). TTTF was significantly longer in R-CVP group as compared with CVP group (27 months vs. 7 months). ORR rates were $81 \%$ and $57 \%$, respectively, indicating superior tumor control in rituximab group with prolonged duration of response (35 months vs. 14 months). Concerning toxicity profile, the addition of rituximab resulted in infusion reactions that were manageable and higher rates of neutropenia but without any clinical repercussion. The authors conclude that R-CVP represents a novel, improved standard of care in FL, which was recognized by regulatory agencies ${ }^{24}$. The results of this study were updated with a longer follow up of 53 months showing the superiority of R-CVP with OS benefit (83\% vs. $77 \%)^{25}$. Subsequently, additional improvements of the first line rituximab-containing regimen were explored. Rituximab was also included in the anthracyclinebased $\mathrm{CHOP}$ regimen in a trial including 428 high tumor burden FL patients ${ }^{26}$. Better ORRs, longer time to treatment failure (60\% TTTF reduction) and duration of response, and better 2-year OS rates (95\% vs. 90\%) were achieved with R-CHOP as compared to CHOP. This study added to the on-going heated discussion whether to use anthracyclines in the frontline therapy for better tumor control in FL. A meta-analysis that included four clinical trials was performed to answer this review question ${ }^{27}$. Therapy with $\mathrm{R}-\mathrm{CVP}$ enabled higher CRs while R-CHOP was associated with better ORRs. However, the pitfall of this systematic review was not analyzing long term FL outcomes, and the authors conclude that the choice of the regimen should be decided individually based on the need to avoid anthracycline cardiotoxicity in older patients or in young patients where salvage therapy followed by ASCT is planned in the future. A recent Cochrane meta-analysis including 8 randomized control trials investigated the effect of adding anthracycline in treating FL on long term outcomes ${ }^{28}$. No OS benefit was recorded while PFS was in favor of anthracycline usage. However, anthracycline was associated with high- er toxicity, primary cytopenias and cardiotoxicity, which limit its application. The use of $\mathrm{R}-\mathrm{CHOP}$ or $\mathrm{R}-\mathrm{CVP}$ currently depends on the experts' judgment until the large observational trials such as REFLECT-1 provide answer to this question ${ }^{29}$.

First line therapy including rituximab has achieved excellent tumor control and reduction, but the question remains if additional benefit of rituximab may be exploited to reduce relapses and prolong PFS without the need for further cytotoxic treatment.

\section{The Rationale for Rituximab as Maintenance Therapy}

After encouraging results of the pivotal study on rituximab, additional analysis was conducted based on the pharmacokinetics and response ${ }^{20,30}$. Overall, rituximab serum concentrations increased and accumulated after each infusion with slow clearance during post treatment follow up. Additionally, the authors found that serum concentration of rituximab was significantly higher in responders when compared to non-responders, especially during follow up. Additional parameters associated with elevated rituximab concentration were B-cell depletion, reduction of the largest tumor diameter, and the sum of diameter of six largest tumor lesions. The authors conclude that this may represent additional antitumor activity of rituximab and that higher concentrations may have a beneficial clinical effect. These findings were further clinically confirmed in a randomized control trial by Ghielmini et $a l .{ }^{31}$. In 185 treatment naive or relapsed FL patients, rituximab was administered once weekly for four weeks. After induction, they were randomized to receive additional four doses of rituximab every 8 weeks ('prolonged phase') or had no additional therapy. Primary outcome of the study was EFS which was significantly longer in 'prolonged' group (23.2 months vs. 11.8 months). Overall, the risk of disease related event decreased by $60 \%$. The prolonged treatment was not associated with any clinically relevant toxicity. In conclusion, prolonged rituximab exposure is associated with beneficial effects in FL with more favorable outcomes. This trial provided evidence to further explore if rituximab could be used as maintenance therapy for reducing the relapse rates and the need for additional chemotherapy. 


\section{Maintenance with Rituximab in Relapsed Follicular Lymphoma}

The first randomized phase III trial explored rituximab maintenance in 176 patients with relapsed or refractory FL or mantle cell lymphoma ${ }^{32}$. Reinduction was induced with fludarabine, cyclophosphamide and mitoxantrone (FCM) with or without rituximab. Owing to the more favorable ORRs in R-FCM group, first randomization was stopped and additionally recruited patients were allocated to R-FCM group. Second randomization of responding patients involved rituximab maintenance ( 2 courses of 4-times-weekly doses at $3^{\text {rd }}$ and $9^{\text {th }}$ month) and observation. Primary objective of the study was response duration, which was not reached in maintenance group vs. 17 months in observation group after median follow up of 26 months. When analyzing for the subtypes of NHLs, difference persisted in FL patients. Regarding toxicity, only one discontinuation occurred due to severe infusion reactions, but lymphocytopenia was most pronounced without infections.

A rituximab maintenance study in relapsed and refractory FL patients was carried out by EORTC group, involving 456 patients randomized at 1:1 ratio to receive either $\mathrm{R}-\mathrm{CHOP}$ or $\mathrm{CHOP}$ as reinduction therapy ${ }^{33}$. Second randomization included rituximab maintenance administered once in 3 months for 2 years or observation. As expected, the addition of rituximab to $\mathrm{CHOP}$ regimen resulted in better ORRs and PFS. Promising disease control, defined as PFS of 51.5 months was achieved as compared to only 14.9 months in observation arm for the whole group. PFS remained significant when adjusting for $\mathrm{R}-\mathrm{CHOP}$ or
CHOP regimens, for the first time showing that maintenance strategy following the standard of care improved outcomes in these patients. Furthermore, PFS translated in OS benefit with 3-year OS rate was $85.1 \%$ in maintenance group as compared with $77.1 \%$ in observation group. Additional safety risks arose in patients in the maintenance group being more prone to neutropenia (10.8\%) and infections (9\%). This toxicity was manageable and no death related to treatment was recorded. EORTC trial has demonstrated major improvements in care for relapsed or refractory FL patients, leading to approval of rituximab maintenance for this indication ${ }^{20}$. Long term follow up (median 6 years) of the trial was published, again demonstrating better PFS in maintenance group as compared to observation group (3.7 years vs. 1.7 years $)^{34}$. However, the benefit in OS was lost probably due to the bias produced by consequent retreatment regimens containing rituximab. Subsequent meta-analysis included 6 randomized controlled trials including 909 patients with relapsed or refractory $\mathrm{FL}^{35}$. Improved OS was seen in maintenance group with hazard-ratio of death estimated to 0.72 . Therefore, current evidence shows not only PFS, but also OS benefit in this subgroup of patients (Table 3). Accordingly, the Croatian national guidelines for lymphoma diagnostics and management have included rituximab maintenance in second CR or partial remission in transplant ineligible patients $^{19}$.

\section{Rituximab Maintenance as Part of First Line Therapy of Follicular Lymphoma}

Preliminary results of rituximab maintenance therapy after rituximab induction at four weekly doses

Table 3. Summary of selected phase III randomized control trials on maintenance therapy in relapsed or refractory follicular lymphoma

\begin{tabular}{|l|l|l|l|l|}
\hline Study & $\mathrm{N}$ & Reinduction & Primary objective & Overall survival \\
\hline Forstpointner et $a .^{32^{*}}$ & 176 & R-FCM & $\begin{array}{l}\text { Response duration: median } \\
\text { not reached vs. } 17 \text { months }\end{array}$ & $77 \%$ vs. $57 \% \%^{* * * *}$ \\
\hline van Oers et al..$^{33^{* *}}$ & 456 & $\begin{array}{l}\text { R-CHOP } \\
\text { CHOP }\end{array}$ & PFS: 51.5 months vs. 14.9 months & $85.1 \%$ vs. $77.1 \%$ \\
\hline van Oers et al..$^{34^{* * *}}$ & 456 & $\begin{array}{l}\text { R-CHOP } \\
\text { CHOP }\end{array}$ & PFS: 3.7 years vs. 1.7 years & $74.3 \%$ vs. 64.7\% $0^{* * * * *}$ \\
\hline
\end{tabular}

*follow up 26 months, 3-year OS rate; **follow up 33.3 months, 3-year OS rate; ***follow up 6 years, 5-year OS rate; ***nonsignificant; OS = overall survival; R-FCM = rituximab, fludarabine, mitoxantrone, cyclophosphamide; $\mathrm{R}-\mathrm{CHOP}=$ rituximab, cyclophosphamide, doxorubicin, vincristine, prednisone; $\mathrm{CHOP}=$ cyclophosphamide, doxorubicin, vincristine, prednisone 
showed improved PFS, as described previosly ${ }^{31}$. Another study explored this strategy in rituximab-naïve patients $^{36}$. The study enrolled 387 patients suffering from indolent NHL, most of them FL. The induction regimen was CVP. Patients were then randomized either to maintenance therapy (four doses of rituximab monthly at 6-month intervals, 4 courses) or observation arm. Three-year PFS was $68 \%$ in maintenance group versus 33\% in observation group. PFS advantage did not significantly translate into OS rates. More importantly, the study has reported conversion to better response to CVP during rituximab phase in $22 \%$ of patients compared with only $7 \%$ in observation group, indicating that not only rituximab maintenance improved outcomes in terms of PFS, but could additionally improve ORRs to prior induction regimen. No data on toxicity were provided in the study. These studies used historical regimens (CVP, rituximab 4 doses weekly) and the need arose to explore maintenance strategy in contemporary setting. In one of the largest trials to date, PRIMA, which enrolled 1217 patients suffering from untreated high burden FL, newer treatment regimens were used ${ }^{37}$. All patients were treated with one of the following chemotherapy regimens: RCHOP, R-CVP or R-FCM. After the end of treatment, 1019 patients were randomized into rituximab maintenance group (rituximab therapy once in two months for two years) or observation group. Primary endpoint was PFS. The 3-year PFS rate was 74.9\% in rituximab group as compared with $57.6 \%$ in observation group, with median follow up of 36 months. Furthermore, as shown by previous study, this strategy may contribute to conversion to optimal response, i.e. 72 patients with $\mathrm{PR}$ were converted to $\mathrm{CR}$ during the maintenance phase. Once again, PFS did not translate into OS benefit. Results with a longer follow up (median 6 years) have been reported ${ }^{38}$. The 6-year PFS rate was $59.2 \%$ for maintenance group versus $42.7 \%$ in observation group. Time to next lymphoma treatment or chemotherapy was significantly longer in the maintenance group. The maintenance strategy did not affect second line treatment of FL with CRs being similar between the groups. However, no significant difference in OS has been reported. Based on the results of PRIMA trial, rituximab was approved by regulatory agencies for another indication as first line maintenance therapy in previously untreated FL responding to induction therapy ${ }^{24}$.
It should be stressed that one study did not find benefit of maintenance therapy in FL. This trial was conducted in elderly, untreated patients $(\mathrm{N}=234)$ using rituximab, fludarabine, mitoxantrone and dexamethasone (R-FND). Patients were randomized in rituximab maintenance (one dose every four months, total of four doses) or observation arm. Primary endpoint of the study was 2-year PFS reaching $81 \%$ in rituximab group versus $69 \%$ in maintenance group. However, this difference was not statistically significant $(\mathrm{p}=0.226)^{39}$. There may have been several reasons, e.g., short follow up, limited rituximab exposure, small sample underpowered to detect difference and use of non-standard immunochemotherapy regimen in the first line setting. An updated meta-analysis has consistently shown improvement in PFS across various studies $(\mathrm{N}=5)$, but again without translation in $\mathrm{OS}^{35}$. Data on rituximab in first line maintenance therapy treatment of FL are summarized in Table 4.

\section{Controversies Surrounding Maintenance Therapy in Advanced High Burden Follicular Lymphoma: to Maintain or not to Maintain?}

So far, we have described relevant clinical trials of maintenance strategy in FL and several controversies have arisen. This will be discussed regarding routine clinical practice.

\section{The role of autologous stem cell transplantation for relapsed follicular lymphoma in rituximab era}

One of the few clinical trials examining ASCT and conventional therapy $(\mathrm{N}=89)$ showed $\mathrm{OS}$ and PFS benefit, but was performed before the advent of ritux$\mathrm{imab}^{40}$. The largest data set on ASCT comes from various retrospective series (e.g., EBMT), while data on ASCT during rituximab availability are scarce ${ }^{15,41}$. In a retrospective analysis by the French GELA group, 254 patients with relapsed FL were included ${ }^{42}$. $\mathrm{Pa}$ tients treated with rituximab-based regimen had significantly better outcomes (OS and EFS) than those treated with ASCT, but adding rituximab to salvage regimen followed by ASCT resulted in the most efficient disease control (OS and EFS not reached). According to the Croatian national guidelines, salvage chemotherapy containing rituximab followed by ASCT is recommended for young, fit patients without 
Table 4. Data from selected phase III randomized controlled trials on rituximab maintenance following first line therapy in bigh burden follicular lymphoma

\begin{tabular}{|c|c|c|c|c|}
\hline Study & $\mathrm{N}$ & Induction & Primary objective & Overall survival \\
\hline Ghielmini et al. ${ }^{31 *}$ & 64 & $\mathrm{Rx} 4$ & EFS: 36 vs. 19 months & Not reported \\
\hline Hochster et al..$^{36 * *}$ & 288 & $\mathrm{CVP}$ & PFS: 68 vs. 33 months & $92 \%$ vs. $86 \% \%^{* * * * * * * * *}$ \\
\hline Salles et al..$^{37 * * *}$ & 1217 & $\begin{array}{l}\text { R-CVP } \\
\text { R-CHOP } \\
\text { R-FCM }\end{array}$ & PFS:74.9 vs. $57.6 \%$ months & $\begin{array}{l}\text { No significant reduction in hazard } \\
\text { ratio for death }\end{array}$ \\
\hline Salles et al. ${ }^{38 * * * * *}$ & 1217 & $\begin{array}{l}\text { R-CVP } \\
\text { R-CHOP } \\
\text { R-FCM }\end{array}$ & PFS: 59.2 vs. $42.7 \%$ & $84.7 \%$ vs. $88.7^{* * * * * *}$ \\
\hline Vitolo et al. ${ }^{39 * * * * * *}$ & 234 & R-FND & PFS: $81 \%$ vs. $69 \%$ ******** & Not reported for groups \\
\hline
\end{tabular}

*median follow up 35 months; **median follow up 3.7 years, 3-year survival rates; ${ }^{* * * * m e d i a n ~ f o l l o w ~ u p ~} 3$ years, 3-year survival rates; *****median follow up 6 years, 6 -year survival rates; ${ }^{* * * * * *}$ median follow up 2 years, 3 -year survival rates; ${ }^{* * * * * *}$ nonsignificant; $\mathrm{R}=$ rituximab; $\mathrm{CVP}=$ cyclophosphamide, vincristine, prednisone; $\mathrm{CHOP}=$ cyclophosphamide, doxorubicin, vincristine, prednisone; $\mathrm{FCM}=$ fludarabine, mitoxantrone, cyclophosphamide; FND = fludarabine, mitoxantrone, dexamethasone; EFS = event-free survival; PFS = progression-free survival

significant comorbidities ${ }^{19}$. The issue of possible omission of ASCT in FL must be resolved in the context of randomized clinical trial examining ASCT compared to rituximab maintenance approach. To our knowledge, no such trial has been performed. As stated previously, in transplant non-eligible patients, rituximab post-reinduction maintenance approach is a standard of care since benefits are recorded in both PFS and $\mathrm{OS}^{17,18,35}$.

\section{Is progression-free survival a valid endpoint in follicular lymphoma?}

One of the main criticisms of rituximab maintenance therapy in high tumor burden FL is the fact that improvement in PFS has not yet translated in OS benefit by clinical trials and meta-analyse ${ }^{31,35-39,43}$. Several factors affecting OS in FL should be taken into account. First, FL is characterized by an indolent course leading to high OS rates and front-line rituximab contributed to $74.3 \%$ of 5 -year OS rate ${ }^{1,14}$. A follow up longer than 5 years would provide information if PFS will translate in OS. Second, for relapsed patients the established second line rituximab regimens and ASCT may result in additional OS interpretation bias due to long term remissions, which directly influences the OS curve. In a recent review by Korn and Crowley, PFS was highlighted as a powerful endpoint in clinical trials to be included in future studies ${ }^{44}$. In the time of accelerated approvals of cancer drugs on the basis of surrogate endpoints such as response rates with sufficient duration (i.e. pathologic complete response to neoadjuvant therapy in breast cancer) or molecular remissions (e.g., tyrosine kinase inhibitors for chronic myelogenous leukemia), evidence for clear PFS benefit by rituximab maintenance in FL might be considered sufficient ground for inclusion in routine protocols ${ }^{45}$.

\section{To retreat or to maintain?}

Rituximab has been established as maintenance therapy, but its possible role in retreatment was also assessed. The first phase II randomized controlled trial included 114 rituximab naïve and previously relapsed patients with indolent $\mathrm{NHLs}^{46}$. Subjects first received 4 weekly rituximab infusions followed by maintenance (four courses of 4 doses of rituximab every 6 months) or reinduction with rituximab after disease progression. Primary objective was duration of rituximab benefit, which was 31.3 months in maintenance group versus 27.4 months in observation group. However, although the difference in primary outcome was not statistically significant, PFS was significantly longer in the maintenance group (31.7 vs. 7.4 months) with a higher rate of CRs and continuous remissions. When analyzing the results, we must take in account that this trial was designed in the era when rituximab was only approved for relapsed FL. Further bias when interpreting the results may be due to short follow up and unbalanced numbers across the groups 
due to early progressions prior to starting maintenance therapy.

The groundbreaking trial was the RESORT trial including 289 treatment naïve low burden FL patients ${ }^{47}$. After 4 weeks of rituximab induction, the subjects were randomized to either receive single rituximab infusion every 13 weeks (maintenance group) or reinduction in case of progression (retreatment group). The study had two primary objectives, i.e. TTTF and time to first cytotoxic therapy. TTTF did not statistically differ between the groups being 3.9 years in retreatment group versus 4.3 years in maintenance group. Time to first cytotoxic therapy was significantly longer in maintenance group as compared to retreatment group. The authors concluded that the retreat scheme was as efficacious as maintenance strategy, therefore reducing overtreatment in this group. The results of this study were greeted with great enthusiasm by maintenance opponents as the "final nail in maintenance coffin ${ }^{\prime 48,49,53}$. Still, great care should be exercised regarding extrapolation of these results to treatment of advanced FL. Considering the relatively short EFS of 11.8 months in first line rituximab induction therapy without extended use, retreatment strategy may not be as effective in high tumor burden FL, but this presumption was not analyzed. Although the retreatment option with rituximab may be attractive due to the acceptable toxicity profile and probable cost-effective benefit, in the absence of data for advanced FL, standard maintenance therapy should represent good clinical practice.

\section{Toxicity of rituximab maintenance}

Concerning the safety profile of rituximab maintenance, the largest set of data comes from the PRIMA trial $^{37}$. The frequency of adverse events equal and greater than 3 occurred in $24 \%$ of patients in maintenance group as compared to $17 \%$ events in observation group. The most common events were new malignancy (4\%), neutropenia (4\%) and infections (4\%). Discontinuation rate due to adverse events was $4 \%$ in maintenance group. Continuous rituximab exposure can cause low plasma immunoglobulins, but no significant decrease in immunoglubulins $A, M$ and $G$ was found in either group. Also, the incidence of transformation to aggressive diffuse large B cell lymphoma did not differ between the groups and no other safety risks were observed ${ }^{38}$. Safety of rituximab maintenance treatment was investigated in MAXIMA, a phase IIIb trial, including 545 patients with previously untreated or relapsed $\mathrm{FL}^{50}$. Hematologic adverse events equal and greater than 3 occurred in $4.4 \%$ of subjects with the most prominent event being neutropenia (2.4\%), but only 4 cases of febrile neutropenia were recorded. Concerning infections, $4.3 \%$ of events equal or greater than 3 were recorded, with pneumonia as the most frequent one. Infections of grade 1 or 2 were more common, including nasopharyngitis (7.1\%), bronchitis (4.7\%) and sinusitis (4.3\%). Grade 3 or 4 hypoimmunoglobulinemia developed in 4 patients, and in $32 \mathrm{pa}-$ tients hypoimmunoglobulinemia was of prolonged duration, but this event was self-limiting and did not require intervention in most cases.

In a systematic review of rituximab maintenance therapy that included 11 clinical trials and 1009 patients suffering from FL or MCL, suppression of bone marrow and infections were most common toxicities, with $24 \%$ of patients experiencing grade 3 or 4 toxici$t^{51}$. Significantly less toxicity was found in the regimen of 4 weekly rituximab infusions every 6 months compared to PRIMA schedule (once in two months for 2 years), i.e. $12 \%$ and $35 \%$, respectively. The systematic review also included MCL patients, which probably affected the results, as MCL patients are treated with more aggressive therapy in first line treatment (high doses of cytarabine with cumulative toxicity). Rituximab maintenance therapy is associated with few side effects, which are tolerable and mostly do not cause discontinuation. While PRIMA schedule should remain the standard of care, in specific patient populations (elderly, unfit, and those prone to infectious complications) alternative approach with rituximab (four weekly doses every 6 months for four cycles) may be a sound option.

\section{Rituximab maintenance therapy and quality of life}

The World Health Organization defines the quality of life (QoL) as the "individuals' perception of their position in life in the context of the culture and value systems in which they live and in relation to their goals, expectations, standards and concerns" ${ }^{33}$. QoL as an important medical issue has substantial impact on designing of clinical trials, mostly as self-reported secondary endpoint. Two different QoL questionnaires 
were applied in PRIMA trial and no difference was found between maintenance and observation group ${ }^{37}$. This has led to criticism that QoL is not improved in these patients, thus failing in secondary endpoint ${ }^{43}$. This is apparently conflicting, but the treatment did not further deteriorate QoL. Also, patients were censored at the time of progression, so prospective data on the possible deterioration in $\mathrm{QoL}$ during relapse and the true impact of maintenance strategy on QoL will remain unknown. It is important to note that relapsed FL patients experience a rapid decline in QoL, as demonstrated in a series of 222 patients during different disease states, but in relapsed setting ${ }^{53}$. The improvement in QoL as a valid surrogate outcome of treatment was recently raised by a prospective clinical trial including 379 asymptomatic, low tumor burden FL patients ${ }^{9}$. The main question of the trial was comparison of outcomes between the 'watch and wait' strategy versus rituximab treatment. By randomizing patients into three groups ('watch and wait', rituximab induction, and rituximab maintenance), the authors showed the expected improvement in time to next therapy in rituximab groups. Interestingly, the second main endpoint was improvement in QoL. The active approach, i.e. rituximab maintenance, significantly improved QoL in these patients, indicating that active approach towards illness improves many lifestyle aspects, including coping mechanisms and emotional status. QoL as primary endpoint has its drawbacks due to the existence of various, more cost-effective interventions in this group such as psychotherapy ${ }^{54}$. In conclusion, it is hard to extrapolate the findings of these studies, whether maintenance therapy improves QoL of FL patients indeed, but it is important to note that this strategy does not have negative impact, thus suggesting another argument for the validity of this approach.

\section{The cost-effectiveness of rituximab maintenance}

The cost of rituximab maintenance strategy is an important issue ${ }^{43}$. In a recent retrospective health economics US study that included 1002 patients with FL from MEDICARE database, the cumulative one-year cost for patients that progressed was 30,890 USD $(\mathrm{N}=268)$ versus only 8704 USD for those in observation group $(\mathrm{N}=734)^{55}$. The outpatients, inpatients, chemotherapy and acute care visits were more frequent in progression group associated with higher cost of care and its impact on healthcare system. This study indirectly provides the rationale that the prolongation of $\mathrm{PFS}$ in FL patients is associated with lower healthcare burden and costs, and provides evidence that maintenance therapy can indeed be cost-effective. One of earlier cost-effectiveness studies of rituximab maintenance comes from the Swedish group ${ }^{56}$. They based their financial model on the phase III trial in relapsed setting conducted by EORTC group ${ }^{33}$. Incremental cost per quality-adjusted life-years (QALY) was estimated to $12,600 €$ for rituximab group, while the cost per life-years-gained (LYG) was 11,200 €. In all of the simulations, rituximab maintenance was associated with incremental costs which were less than 25,400 €. With regard to willingness-to-pay value in Sweden of up to $54,000 €$ per intervention, rituximab maintenance in relapsed setting was cost-effective. Recently, a Dutch population-based study used registry data comprising 3581 patients with relapsed FL undergoing maintenance therapy ${ }^{57}$. The incremental cost-effectiveness ratio (ICER) was 11,254 € per QALY and 10,591 $€$ per LYG. ICERs slightly differed in two studies (EORTC trial and matched-real world scenarios), but in conclusion rituximab maintenance in relapsed patients was found to be cost-effective and in line with Dutch healthcare policy makers. Similar results were obtained by a French economic analysis based on EORTC trial estimating ICER of $7612 €$ per LYG and $8729 €_{\text {per }}$ QALY $^{33,58}$. These data demonstrate that rituximab maintenance is cost-effective in relapsed FL setting and its ICER is well below willingness-to-pay value for oncologic drug.

The earliest data on rituximab maintenance costeffectiveness in first line setting come from US group based on the results of PRIMA trial ${ }^{37,59}$. Total cost of maintenance therapy was estimated to be 38,545 USD with ICERs being 31,394 and 34,842 USD for LYG and QALY, respectively. The majority of US studies use ICER per QALY threshold as 50,000 USD, this approach seems to be cost-effective from US point of $v^{2} w^{60}$. In Europe, only one health economics study from the UK National Institute for Health and Care Excellence examined rituximab maintenance ${ }^{61}$. Most of ICERs per QALY were under 30,000 GBP, as reported by the manufacturer, while Evidence Review Group estimated ICERs per QALY to range between 
24,600 and 35,000 GBP based on the scenario. The review group has concluded that rituximab maintenance is cost effective for the National Health System resources, which evaluate ICER per QALY as 30,000 GBP. Data were from primary PRIMA study with a short follow up, which possibly influenced the results. Future studies including real-world data are needed to address this issue.

\section{Rituximab maintenance at the dawn of new drugs for indolent non-Hodgkin lymphoma: still necessary?}

The past several years have certainly been exciting for indolent NHLs, particularly FL with the introduction of new drugs possibly changing treatment options. The first drug of interest is certainly bendamustine (B), an 'old', but new drug in the field. Bendamustine acts as a potent alkylating agent, indeed more potent than cyclophosphamide ${ }^{62}$, which also is not cross-resistant with other members from the group. The activity of bendamustine was demonstrated in early clinical trials in refractory or relapsed indolent NHLs resulting in high ORRs and durable remissions as a single agent or in combination therapy resulting in FDA approval for rituximab-resistant indolent $\mathrm{NHLs}^{63}$. However, the true value of bendamustine was recognized in first line therapy of iNHLs. First randomized clinical trial compared bendamustine in combination with rituximab (R-B) to standard R$\mathrm{CHOP}$ therapy in indolent and mantle cell lymphomas $^{64}$. This combination resulted in improved PFS when compared to standard arm across all NHLs histology. Also, its toxicity was more tolerable with fewer hematologic and other adverse events (mostly infections). The results of this trial produced the hype that the era of R-CHOP had ended ${ }^{65}$. However, despite the non-inferiority design, BRIGHT study compared $\mathrm{R}-\mathrm{B}$ to $\mathrm{R}-\mathrm{CHOP}$ or R-CVP and did not demonstrate superiority in terms of ORRs, while PFS was not reported $^{70}$. Adverse events included more hypersensitivity reactions, vomiting and nausea, and infection rate was not reduced. These results sparked doubt on the role of bendamustine in first line treatment and ongoing controversy whether $\mathrm{B}-\mathrm{R}$ regimen should replace current standard regimens in FL and has not been granted universal approval for this indication. Nevertheless, ever more patients are being treated with $\mathrm{B}-\mathrm{R}$ regimen questioning appropriateness of which has led to the question whether subsequent rituximab maintenance still plays a role in this setting. Rituximab maintenance following B-R induction is being evaluated in the ongoing MAINTAIN study ${ }^{67}$. Preliminary results have shown feasibility of the approach, but we will have to wait if difference in PFS will be achieved between maintenance arms and observation arm.

The greatest challenge to rituximab maintenance poses the relatively new introduction of $\mathrm{B}$-cell receptor (BCR) pathway inhibitors into the field of NHLs ${ }^{68}$. These agents have rapidly changed therapy approach as tyrosine kinase inhibitors. In indolent NHLs, the most important member of the class is currently idelalisib, a phophatidylinositol-3 kinase $\delta$ inhibitor. Based on the preliminary data on its activity in indolent NHLs, a randomized, clinical trial was performed on 125 heavily pretreated patients with indolent NHLs ${ }^{69}$. Idelalisib has shown satisfactory activity with ORR of $57 \%$ and median duration of response of 12.5 months, which was granted by FDA approval for refractory and relapsed indolent $\mathrm{NHLs}^{70}$. Although this agent alone cannot produce durable CRs, its low toxicity in relapsed setting and new mechanism of action make idelalisib a preferable target for various combinations. Recently, a great setback has occurred with idelalisib ${ }^{71}$. The interim safety analysis of trials exploring idelalisib in combinations with cytotoxic drugs has shown inferior OS due to toxicity profile (Pneumocystis jirovecii infections, cytomegalovirus reactivation, high rates of transaminitis and pneumonitis), which led to suspension of RCTs in first line setting. Other BCR pathway inhibitors for indolent NHLs, such as venetoclax, are explored in phase I/II trials and proper introduction of these agents in real time clinical practice will not occur soon.

\section{Conclusion}

The existing data indicate that rituximab maintenance in advanced high tumor FL is efficient for:

1. prolonged PFS

2. prolonged $\mathrm{OS}$ in relapsed $\mathrm{FL}$

3. optimization of response

4. low toxicity profile

5. adequate cost-benefit profile

6. no negative interference with QoL

Recommended treatment algorithms are presented in Figures 1 and 2. Rituximab maintenance may be used in first and second line treatment of advanced 


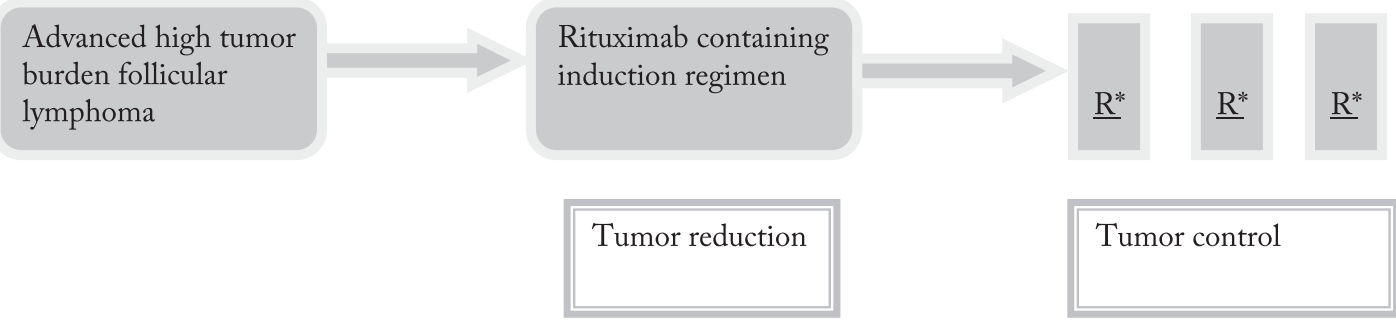

*Maintenance in case of complete or partial remission, dosing schedule according to PRIMA study ${ }^{37}$

Fig. 1. Preferred treatment algorithm for previously untreated advanced high tumor burden follicular lymphoma ${ }^{72}$.

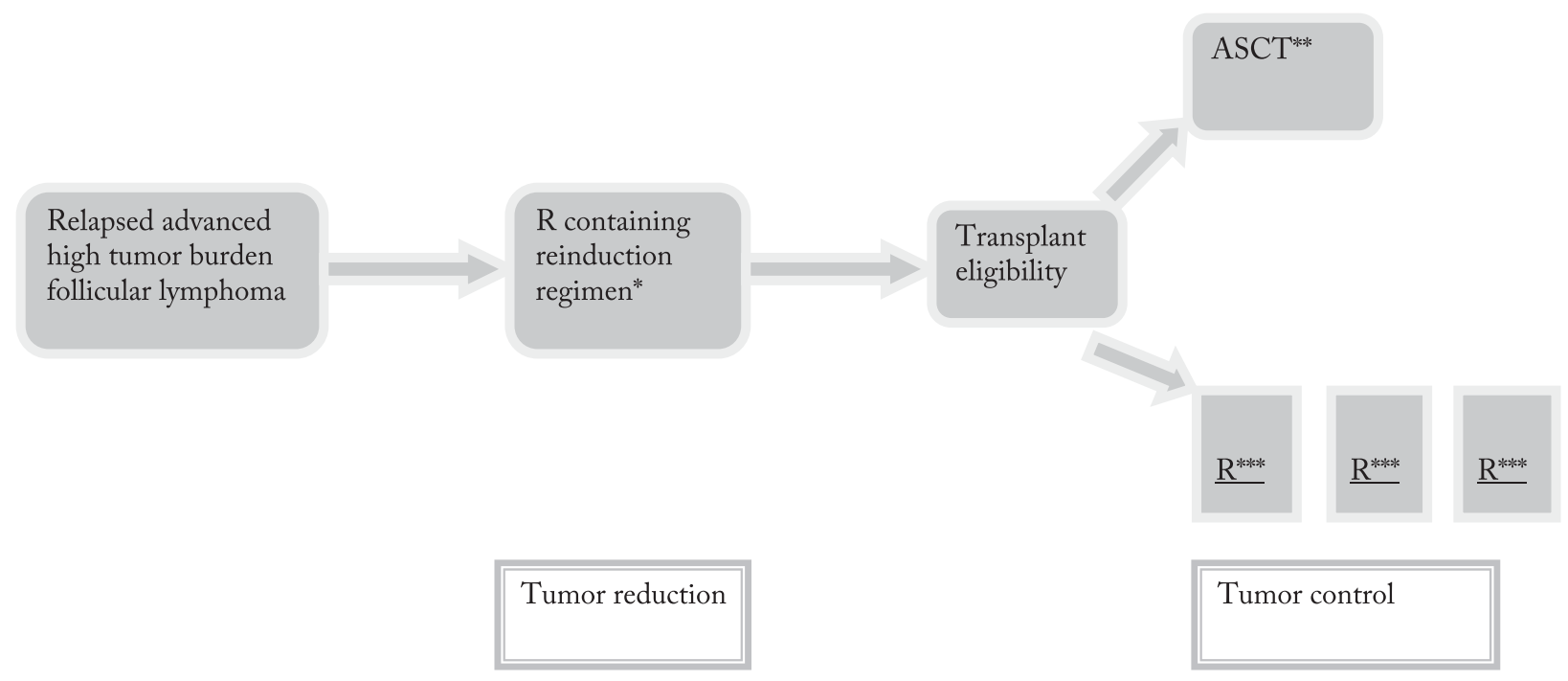

*include rituximab if first remission is longer than 6 months $^{19}$; * proceed to ASCT in case of complete or partial remission in transplanteligible patient; ${ }^{* * *}$ rituximab maintenance in case of complete or partial remission in transplant-ineligible patient, use EORTC dosing schedule $^{33}$

Fig. 2. Preferred treatment algorithm for relapsed advanced stage high tumor burden follicular lymphoma.

high tumor burden FL according to the national guidelines for lymphoma diagnosis and treatment ${ }^{19}$. Despite current controversies surrounding this strategy, current data suggest that rituximab maintenance may and need to be employed in modern treatment of FL.

\section{Acknowledgment.}

We thank Professor Vesna Kušec for help with preparation of the manuscript.

\section{References}

1. Al-Hamadani M, Habermann TM, Cerhan JR, Macon WR, Maurer MJ, Go RS. Non-Hodgkin lymphoma subtype distribution, geodemographic patterns, and survival in the US: a lon- gitudinal analysis of the National Cancer Data Base from 1998 to 2011. Am J Hematol. 2015;90:790-5. https://doi.org/10. 1002/ajh.24086

2. Jaffe ESHN, Stein H, Vardiman JW, editors. World Health Organization Classification of Tumours: Pathology and Genetics of Tumours of Haematopoietic and Lymphoid Tissues. Lyon: IARC Press; 2001.

3. Novak I, Jakšić O, Kuliš T, Batinjan K, Znaor A. Incidence and mortality trends of leukemia and lymphoma in Croatia, 19882009. Croat Med J. 2012;53:115-23.

4. Dotlic S, Perry AM, Petrusevska G, Fetica B, Diebold J, MacLennan KA, et al. Classification of non-Hodgkin lymphoma in south-eastern Europe: review of 632 cases from the international non-Hodgkin lymphoma classification project. Br J Haematol. 2015;171:366-72. https://doi.org/10.1111/bjh.13586

5. Xerri L, Dirnhofer S, Quintanilla-Martinez L, Sander B, Chan JK, Campo E, et al. The heterogeneity of follicular lymphomas: 
from early development to transformation. Virchows Arch. 2015; 468:127-39. https://doi.org/10.1007/s00428-015-1864-y

6. Freedman A. Follicular lymphoma: 2014 update on diagnosis and management. Am J Hematol. 2014;89:429-36. https://doi. org/10.1002/ajh.23674

7. Solal-Céligny P, Lepage E, Brousse N, Tendler CL, Brice P, Haïoun $\mathrm{C}$, et al. Doxorubicin-containing regimen with or without interferon alfa-2b for advanced follicular lymphomas: final analysis of survival and toxicity in the Groupe d'Etude des Lymphomes Folliculaires 86 Trial.J Clin Oncol. 1998;16:23328. https://doi.org/10.1200/JCO.1998.16.7.2332

8. Hagemeister FB. 'Watch and wait' as initial management for patients with follicular lymphomas: still a viable strategy? BioDrugs. 2012;26:363-76. https://doi.org/10.2165/11634320000000000-00000

9. Ardeshna KM, Qian W, Smith P, Braganca N, Lowry L, Patrick $\mathrm{P}$, et al. Rituximab versus a watch-and-wait approach in patients with advanced-stage, asymptomatic, non-bulky follicular lymphoma: an open-label randomised phase 3 trial. Lancet Oncol. 2014;15:424-35. https://doi.org/10.1016/S1470-2045 (14)70027-0

10. Solal-Céligny P, Roy P, Colombat P, White J, Armitage JO, Arranz-Saez R, et al. Follicular lymphoma international prognostic index. Blood. 2004;104:1258-65. https://doi.org/10. 1182/blood-2003-12-4434

11. Federico M, Bellei M, Marcheselli L, Luminari S, LopezGuillermo A, Vitolo U, et al. Follicular lymphoma international prognostic index 2: a new prognostic index for follicular lymphoma developed by the international follicular lymphoma prognostic factor project. J Clin Oncol. 2009;27:4555-62. https://doi.org/10.1200/JCO.2008.21.3991

12. Qazi R, Aisenberg AC, Long JC. The natural history of nodular lymphoma. Cancer. 1976;37:1923-7.

13. De Angelis R, Sant M, Coleman MP, Francisci S, Baili P, Pierannunzio D, et al. Cancer survival in Europe 1999-2007 by country and age: results of EUROCARE-5 - a populationbased study. Lancet Oncol. 2014;15:23-34. https://doi.org/ 10.1016/S1470-2045(13)70546-1

14. Sant M, Minicozzi P, Mounier M, Anderson LA, Brenner $\mathrm{H}$, Holleczek B, et al. Survival for haematological malignancies in Europe between 1997 and 2008 by region and age: results of EUROCARE-5, a population-based study. Lancet Oncol. 2014;15:931-42. https://doi.org/10.1016/S1470-2045 (14)70282-7

15. Montoto S, Canals C, Rohatiner AZ, Taghipour G, Sureda A, Schmitz N, et al. Long-term follow-up of high-dose treatment with autologous haematopoietic progenitor cell support in 693 patients with follicular lymphoma: an EBMT registry study. Leukemia. 2007;21:2324-31. https://doi.org/10.1038/sj.leu. 2404850

16. Rohatiner AZ, Nadler L, Davies AJ, Apostolidis J, Neuberg D, Matthews J, et al. Myeloablative therapy with autologous bone marrow transplantation for follicular lymphoma at the time of second or subsequent remission: long-term follow-up. J Clin Oncol. 2007;25:2554-9. https://doi.org/10.1200/JCO.2006.09.8327
17. Zelenetz AD, Gordon LI, Wierda WG. NCCN Clinical Practice Guidelines in Oncology (NCCN Guidelines) Non-Hodgkin's Lymphomas Version 2/2015. Accessed 11/17/2015 http:// www.nccn.org/professionals/physician_gls/pdf/nhl.pdf

18. Dreyling M, Ghielmini M, Marcus R, Salles G, Vitolo U, Ladetto M. Newly diagnosed and relapsed follicular lymphoma: ESMO Clinical Practice Guidelines for diagnosis, treatment and follow-up. Ann Oncol. 2014;25:iii76-82. https://doi. org/10.1093/annonc/mdu200

19. Aurer I, Gasparov S, Kralik M, Balenović A, Huić D, Santek F, et al. Lymphoma diagnosis and treatment - second Croatian consensus. Lijec Vjesn. 2013;135:63-76. (in Croatian)

20. McLaughlin P, Grillo-López AJ, Link BK, Levy R, Czuczman MS, Williams ME, et al. Rituximab chimeric anti-CD20 monoclonal antibody therapy for relapsed indolent lymphoma: half of patients respond to a four-dose treatment program. J Clin Oncol. 1998;16:2825-33. https://doi.org/10.1200/ JCO.1998.16.8.2825

21. Grillo-López AJ, White CA, Varns C, Shen D, Wei A, McClure A, et al. Overview of the clinical development of rituximab: first monoclonal antibody approved for the treatment of lymphoma. Semin Oncol. 1999;26:66-73.

22. Demidem A, Lam T, Alas S, Hariharan K, Hanna N, Bonavida B. Chimeric anti-CD20 (IDEC-C2B8) monoclonal antibody sensitizes a B cell lymphoma cell line to cell killing by cytotoxic drugs. Cancer Biother Radiopharm. 1997;12:177-86. https://doi.org/10.1089/cbr.1997.12.177

23. Marcus R, Imrie K, Belch A, Cunningham D, Flores E, Catalano J, et al. CVP chemotherapy plus rituximab compared with CVP as first-line treatment for advanced follicular lymphoma. Blood. 2005;105:1417-23. https://doi.org/10.1182/ blood-2004-08-3175

24. Storz U. Rituximab: how approval history is reflected by a corresponding patent filing strategy. MAbs. 2014;6:820-37. https: //doi.org/10.4161/mabs.29105

25. Marcus R, Imrie K, Solal-Celigny P, Catalano JV, Dmoszynska A, Raposo JC, et al. Phase III study of R-CVP compared with cyclophosphamide, vincristine, and prednisone alone in $\mathrm{pa}^{-}$ tients with previously untreated advanced follicular lymphoma. J Clin Oncol. 2008;26:4579-86. https://doi.org/10.1200/ JCO.2007.13.5376

26. Hiddemann W, Kneba M, Dreyling M, Schmitz N, Lengfelder $\mathrm{E}, \mathrm{Schmits} \mathrm{R}$, et al. Frontline therapy with rituximab added to the combination of cyclophosphamide, doxorubicin, vincristine, and prednisone (CHOP) significantly improves the outcome for patients with advanced-stage follicular lymphoma compared with therapy with $\mathrm{CHOP}$ alone: results of a prospective randomized study of the German Low-Grade Lymphoma Study Group. Blood. 2005;106:3725-32. https://doi.org/10. 1182/blood-2005-01-0016

27. Siddhartha G, Vijay P. R-CHOP versus R-CVP in the treatment of follicular lymphoma: a meta-analysis and critical appraisal of current literature. J Hematol Oncol. 2009;2:14. https://doi.org/10.1186/1756-8722-2-14 
28. Itchaki G, Gafter-Gvili A, Lahav M, Vidal L, Raanani P, Shpilberg O, et al. Anthracycline-containing regimens for treatment of follicular lymphoma in adults. Cochrane Database Syst Rev. 2013;7:CD008909. https://doi.org/10.1002/146518 58.CD008909.pub2

29. Hoffmann-La Roche. Rituximab therapy in follicular lymphoma in combination with chemotherapy - REFLECT 1 . In Clinical Trials.gov [Internet]. Bethesda (MD): National library of Medicine. 2013. [cited 20 Nov 2015] Available from URL: https:/clinicaltrials.gov/ct2/show/NCT02461290?term=follic ular+lymphoma\&rank=107 NLM identifier: NCT02461290

30. Berinstein NL, Grillo-López AJ, White CA, Bence-Bruckler I, Maloney D, Czuczman M, et al. Association of serum rituximab (IDEC-C2B8) concentration and anti-tumor response in the treatment of recurrent low-grade or follicular non-Hodgkin's lymphoma. Ann Oncol. 1998;9:995-1001.

31. Ghielmini M, Schmitz SF, Cogliatti SB, Pichert G, Hummerjohann J, Waltzer U, et al. Prolonged treatment with rituximab in patients with follicular lymphoma significantly increases event-free survival and response duration compared with the standard weekly x4 schedule. Blood. 2004;103:4416-23. https://doi.org/10.1182/blood-2003-10-3411

32. Forstpointner R, Unterhalt M, Dreyling M, Böck HP, Repp R, Wandt $\mathrm{H}$, et al. Maintenance therapy with rituximab leads to a significant prolongation of response duration after salvage therapy with a combination of rituximab, fludarabine, cyclophosphamide, and mitoxantrone (R-FCM) in patients with recurring and refractory follicular and mantle cell lymphomas: results of a prospective randomized study of the German Low Grade Lymphoma Study Group (GLSG). Blood. 2006;108: 4003-8. https://doi.org/10.1182/blood-2006-04-016725

33. van Oers MH, Klasa R, Marcus RE, Wolf M, Kimby E, Gascoyne $\mathrm{RD}$, et al. Rituximab maintenance improves clinical outcome of relapsed/resistant follicular non-Hodgkin lymphoma in patients both with and without rituximab during induction: results of a prospective randomized phase 3 intergroup trial. Blood. 2006;108:3295-301. https://doi.org/10.1182/blood2006-05-021113

34. van Oers MH, Van Glabbeke M, Giurgea L, Klasa R, Marcus $\mathrm{RE}$, Wolf $\mathrm{M}$, et al. Rituximab maintenance treatment of relapsed/resistant follicular non-Hodgkin's lymphoma: longterm outcome of the EORTC 20981 phase III randomized intergroup study. J Clin Oncol. 2010;28:2853-8. https://doi. org/10.1200/JCO.2009.26.5827

35. Vidal L, Gafter-Gvili A, Salles G, Dreyling MH, Ghielmini M, Hsu Schmitz SF, et al. Rituximab maintenance for the treatment of patients with follicular lymphoma: an updated systematic review and meta-analysis of randomized trials. J Natl Cancer Inst.2011;103:1799-806.https://doi.org/10.1093/ jnci/djr418

36. Hochster H, Weller E, Gascoyne RD, Habermann TM, Gordon LI, Ryan T, et al. Maintenance rituximab after cyclophosphamide, vincristine, and prednisone prolongs progression-free survival in advanced indolent lymphoma: results of the randomized phase III ECOG1496 study. J Clin Oncol. 2009; 27:1607-14. https://doi.org/10.1200/JCO.2008.17.1561
37. Salles G, Seymour JF, Offner F, López-Guillermo A, Belada D, Xerri L, et al. Rituximab maintenance for 2 years in patients with high tumour burden follicular lymphoma responding to rituximab plus chemotherapy (PRIMA): a phase 3, randomised controlled trial. Lancet. 2011;377:42-51. https://doi.org/10. 1200/JCO.2008.17.1561

38. Salles G, Seymour JF, Feugier P, Offner F, Lopez-Guillermo A, Belada D, et al. Updated 6 year follow-up of the PRIMA study confirms the benefit of 2-year rituximab maintenance in follicular lymphoma patients responding to frontline immunochemotherapy. Blood. 2013;122:509.

39. Vitolo U, Ladetto M, Boccomini C, Baldini L, De Angelis F, Tucci A, et al. Rituximab maintenance compared with observation after brief first-line R-FND chemoimmunotherapy with rituximab consolidation in patients older than 60 years with advanced follicular lymphoma: a phase III randomized study by the Fondazione Italiana Linfomi. J Clin Oncol. 2013; 31:3351-9.

40. Schouten HC, Qian W, Kvaloy S, Porcellini A, Hagberg H, Johnsen HE, et al. High-dose therapy improves progressionfree survival and survival in relapsed follicular non-Hodgkin's lymphoma: results from the randomized European CUP trial.J Clin Oncol. 2003;21:3918-27. https://doi.org/10.1200/JCO. 2003.10.023

41. Hamadani M. Reappraising the role of autologous transplantation for indolent B-cell lymphomas in the chemoimmunotherapy era: is it still relevant? Bone Marrow Transplant. 2013; 48:1013-21. https://doi.org/10.1038/bmt.2012.182

42. Sebban C, Brice P, Delarue R, Haioun C, Souleau B, Mounier $\mathrm{N}$, et al. Impact of rituximab and/or high-dose therapy with autotransplant at time of relapse in patients with follicular lymphoma: a GELA study.J Clin Oncol.2008;26:3614-20.https:// doi.org/10.1200/JCO.2007.15.5358

43. Haines I. Rituximab maintenance therapy for follicular lymphoma. Lancet. 2011;377:1151-2. https://doi.org/10.1016/ S0140-6736(11)60459-5

44. Korn RL, Crowley JJ. Overview: progression-free survival as an endpoint in clinical trials with solid tumors. Clin Cancer Res. 2013;19:2607-12. https://doi.org/10.1158/1078-0432.CCR12-2934

45. Johnson JR, Ning YM, Farrell A, Justice R, Keegan P, Pazdur R. Accelerated approval of oncology products: the Food and Drug Administration experience. J Natl Cancer Inst. 2011; 103:636-44. https://doi.org/10.1093/jnci/djr062

46. Hainsworth JD, Litchy S, Shaffer DW, Lackey VL, Grimaldi M, Greco FA. Maximizing therapeutic benefit of rituximab: maintenance therapy versus re-treatment at progression in $\mathrm{pa}-$ tients with indolent non-Hodgkin's lymphoma - a randomized phase II trial of the Minnie Pearl Cancer Research Network. J Clin Oncol. 2005;23:1088-95.

47. Kahl BS, Hong F, Williams ME, Gascoyne RD, Wagner LI, Krauss JC, et al. Rituximab extended schedule or re-treatment trial for low-tumor burden follicular lymphoma: Eastern $\mathrm{Co}_{-}$ operative Oncology Group protocol e4402.J Clin Oncol. 2014; 32:3096-102. 
48. Friedberg JW. End of rituximab maintenance for low-tumor burden follicular lymphoma. J Clin Oncol. 2014;32:3093-5. https://doi.org/10.1200/JCO.2005.12.191

49. Cheson B. Reason to RESORT to rituximab maintenance? Accessed online 12/2/2015 http://www.medscape.com/viewarticle/756805

50. Witzens-Harig M, Foá R, Di Rocco A, van Hazel G, Chamone DF, Rowe JM, et al. Maintenance with rituximab is safe and not associated with severe or uncommon infections in patients with follicular lymphoma: results from the phase IIIb MAXIMA study. Ann Hematol. 2014;93:1717-24. https://doi. org/10.1007/s00277-014-2103-3

51. Nabhan C, Ollberding NJ, Villines D, Chiu BC, Caces DB, Valdez TV, et al. A systematic review of comparative schedulerelated toxicities with maintenance rituximab in follicular and mantle cell lymphomas. Leuk Lymphoma. 2014;55:1288-94. https://doi.org/10.3109/10428194.2013.839787

52. The World Health Organization Quality of Life assessment (WHOQOL): position paper from the World Health Organization. Soc Sci Med. 1995;41:1403-9.

53. Pettengell R, Donatti C, Hoskin P, Poynton C, Kettle PJ, Hancock B, et al. The impact of follicular lymphoma on health-related quality of life. Ann Oncol. 2008;19:570-6. https://doi. org/10.1093/annonc/mdm543

54. LeBlanc T, Kamal A, Abernethy A. Rituximab for follicular lymphoma: watch and wait, watch and worry, or watch and live? Lancet Oncol. 2014;15:e251-2. https://doi.org/10.1016/ S1470-2045(14)70215-3

55. Beveridge R, Satram-Hoang S, Sail K, Darragh J, Chen C, Forsyth $\mathrm{M}$, et al. Economic impact of disease progression in follicular non-Hodgkin lymphoma. Leuk Lymphoma. 2011; 52:2117-23. https://doi.org/10.3109/10428194.2011.592623

56. Kasteng F, Erlanson M, Hagberg H, Kimby E, Relander T, Lundkvist J. Cost-effectiveness of maintenance rituximab treatment after second line therapy in patients with follicular lymphoma in Sweden. Acta Oncol. 2008;47:1029-36. https:// doi.org/10.1080/02841860802120028

57. Blommestein HM, Issa DE, Pompen M, Ten Hoor G, Hogendoorn $\mathrm{M}$, Joosten $\mathrm{P}$, et al. Cost-effectiveness of rituximab as maintenance treatment for relapsed follicular lymphoma: results of a population-based study. Eur J Haematol.2014;92:398406. https://doi.org/10.1111/ejh.12264

58. Deconinck E, Miadi-Fargier H, Pen CL, Brice P. Cost effectiveness of rituximab maintenance therapy in follicular lymphoma: long-term economic evaluation. Pharmacoeconomics. 2010;28:35-46. https://doi.org/10.2165/11314070-000000000 $-00000$

59. Hornberger J, Chien R, Friedmann M, Han L, Shewade A, Satram-Hoang S, et al. Cost-effectiveness of rituximab as maintenance therapy in patients with follicular non-Hodgkin lymphoma after responding to first-line rituximab plus chemotherapy. Leuk Lymphoma. 2012;53:2371-7. https://doi.org /10.3109/10428194.2012.694429
60. Chhatwal J, Mathisen M, Kantarjian H. Are high drug prices for hematologic malignancies justified? A critical analysis. Cancer. 2015;121:3372-9.

61. Greenhalgh J, Bagust A, Boland A, Blundell M, Oyee J, Beale $\mathrm{S}$, et al. Rituximab for the first-line maintenance treatment of follicular non-Hodgkin's lymphoma: a NICE single technology appraisal. Pharmacoeconomics. 2013;31:403-13. https:// doi.org/10.1007/s40273-013-0043-8

62. Darwish M, Bond M, Hellriegel E, Robertson P Jr, Chovan JP. Pharmacokinetic and pharmacodynamic profile of bendamustine and its metabolites. Cancer Chemother Pharmacol. 2015;75:1143-54. https://doi.org/10.1007/s00280-015-2727-6

63. Tageja N, Nagi J. Bendamustine: something old, something new. Cancer Chemother Pharmacol. 2010;66:413-23. https:// doi.org/10.1007/s00280-010-1317-x

64. Rummel MJ, Niederle N, Maschmeyer G, Banat GA, von Grünhagen U, Losem C, et al. Bendamustine plus rituximab versus $\mathrm{CHOP}$ plus rituximab as first-line treatment for patients with indolent and mantle-cell lymphomas: an open-label, multicentre, randomised, phase 3 non-inferiority trial. Lancet. 2013;381:1203-10. https://doi.org/10.1016/S0140-6736(12) 61763-2

65. Jacobson CA, Freedman AS. First-line treatment of indolent lymphoma: axing CHOP? Lancet. 2013;381:1163-5. https:// doi.org/10.1016/S0140-6736(12)61965-5

66. Flinn IW, van der Jagt R, Kahl BS, Wood P, Hawkins TE, Macdonald D, et al. Randomized trial of bendamustine-rituximab or R-CHOP/R-CVP in first-line treatment of indolent NHL or MCL: the BRIGHT study. Blood. 2014;123:294452. https://doi.org/10.1182/blood-2013-11-531327

67. Rummel MJ, Viardot A, Greil R, et al. Bendamustine plus rituximab followed by rituximab maintenance for patients with untreated advanced follicular lymphomas. Results from the StiL NHL 7-2008 Trial (MAINTAIN trial) (ClinicalTrials. gov Identifier: NCT00877214). Blood 2014;124:3052.

68. Sawas A, Diefenbach C, O`Connor OA. New therapeutic targets and drugs in non-Hodgkin's lymphoma. Curr Opin Hematol. 2011;18:280-7. https://doi.org/10.1097/MOH.0b013e $328347786 \mathrm{~d}$

69. Gopal AK, Kahl BS, de Vos S, Wagner-Johnston ND, Schuster SJ, Jurczak WJ, et al. PI3K $\delta$ inhibition by idelalisib in patients with relapsed indolent lymphoma. N Engl J Med. 2014;370: 1008-18. https://doi.org/10.1056/NEJMoa1314583

70. Miller BW, Przepiorka D, de Claro RA, Lee K, Nie L, Simpson $\mathrm{N}$, et al. FDA approval: idelalisib monotherapy for the treatment of patients with follicular lymphoma and small lymphocytic lymphoma. Clin Cancer Res. 2015;21:1525-9. https:// doi.org/10.1158/1078-0432.CCR-14-2522

71. European Medicines Agency. EMA reviews cancer medicine Zydelig. Accessed online 14/4/2015 from http://www.ema.europa.eu/ema/index.jsp?curl=pages/news_and_events/news $/ 2016$ /03/news_detail_002487.jsp\&mid=WC0b01ac058004d5c1

72. Hiddemann W, Cheson BD. How we manage follicular lymphoma. Leukemia. 2014;28:1388-95. https://doi.org/10.1038/ leu.2014.91 
Sažetak

\section{ODRŽAVANJE RITUKSIMABOM U UZNAPREDOVALOM FOLIKULARNOM LIMFOMU: KONTROVERZIJE}

\section{Milunović, M. Bogeljić Patekar, K. Mišura Jakubac, I. Mandac Rogulj, D. Radić-Krišto, A. Planinc-Peraica i S. Ostojić Kolonić}

Rituksimab je kimerično antiCD20 protutijelo koje se koristi u liječenju CD20 pozitivnih ne-Hodgkinovih limfoma te je promijenilo paradigmu liječenja ovih hematoloških neoplazma u prošlom desetljeću. Glavni cilj ovoga preglednog rada je predstaviti njegovu primjenu u folikularnom limfomu (FL) s naglaskom na terapiju održavanja. Ova strategija doprinijela je boljem preživljenju bez progresije bolesti u prvoj i drugoj liniji terapije, odnosno boljem ukupnom preživljenju u bolesnika s relapsom FL-a. No, usprkos dobrim rezultatima, održavanje rituksimabom je doprinijelo kontroverzi u medicinskoj zajednici. Navedene nedoumice potječu od nedostatka poboljšanja ukupnog preživljenja u prvoj liniji terapije, moguće toksičnosti do nepoznate uloge u eri novih lijekova za liječenje FL-a. Prema postojećim podacima zaključujemo da terapiju održavanja rituksimabom treba ponuditi bolesnicima s FL-om koji su odgovorili na prvu liniju terapije te bolesnicima s relapsom FL-a koji su odgovorili na reindukciju, a nisu kandidati za liječenje autolognom transplantacijom matičnih stanica.

Ključne riječi: Rituksimab; Limfom, ne-Hodgkinov-terapija; Limfom, folikularni; Terapija održavanja; Ishod liječenja 